\title{
PENGARUH MODEL PEMBELAJARAN KOOPERATIF TIPE NUMBERED HEADS TOGETHER (NHT) BERBANTUAN LKPD TERDAHAP KEMAMPUAN BERPIKIR KREATIF FISIKA PESERTA DIDIK DI SMAN 3 MATARAM
}

\author{
Yuli*, Hairunnisyah Sahidu, Syahrial Ayub \\ Program Studi Pendidikan Fisika, Universitas Mataram \\ *Email: yuliakfal91@gmail.com
}

\begin{abstract}
This research aimed to examine the effect of Numbered Heads Together (NHT) cooperative learning model LKPD aided toward student's ability to think creatively in physics. This quasiexperiment research used untreated control group design with pre-test and post-test. The population of research are all students XI MIA in SMAN 3 Mataram, amounting to 349 people. Sampling research using purposive sampling technique, so selected XI class MIA 3 as experimental class and XI MIA 4 as a control class. The experimental class was given treatment in the form of cooperative learning model of NHT type supported by LKPD and control class was given treatment in the form of direct teaching model. The data collection of creative thinking ability is done by the form of a description test as many as 10 questions consisting of 7 questions of verbal creativity and 3 figural creativity questions. Creativity data was analyzed by using t-test polled variance at $5 \%$ significant level with degrees of freedom 73. The results of research on the influence of cooperative learning model type NHT assisted LKPD on the ability of creative thinking physics learners obtained $t_{\text {continue }}>$ $t_{(0,05 ; 73)}=3,63>2,00$. Based on the results of this analysis can be concluded that cooperative learning model type NHT aided LKPD effect on the ability of creative thinking physics learners in SMAN 3 Mataram.
\end{abstract}

Keyword: NHT, cooperative learning model, creative thinking ability.

\section{PENDAHULUAN}

Perkembangan teknologi dan informasi saat ini sangatlah pesat. Perkembangan itu juga diiringi dengan semakin cepatnya perkembangan ilmu pengetahuan dan teknologi. Sudah banyak produk dan manfaat yang diperoleh dari perkembangan tersebut, salah satunya dalam dunia pendidikan. Dalam dunia pendidikan, perkembangan tehnologi dan informasi sangat membantu peran pengajar (guru) dalam melaksanakan tugasnya di dalam kelas, misalnya kesiapan dan kemampuan guru untuk mengajar seperti menyiapkan atau merencanakan metode atau model pembelajaran yang menarik untuk diperhatikan oleh peserta didik. Faktanya, kemampuan guru dalam memilih metode atau model pembelajaran di sekolah masih kurang tepat serta tidak bervariatif, kebanyakan masih menggunakan metode ceramah dimana metode ini hanya berpusat pada guru serta proses pembelajaran yang hanya berisi penjelasan materi dan pemberian latihan soal.

Berdasarkan hasil observasi yang telah dilakukan di SMAN 3 Mataram, ada beberapa permasalahan yang peneliti temukan yaitu, proses pembelajaran fisika kurang mengaktifkan peserta didik, diakibatkan oleh pemilihan model, strategi, dan metode pembelajaran yang kurang tepat sehingga kurangnya antusias, kemauan, dan kesadaran peserta didik untuk mengajukan pertanyaan serta kurang mampu mengutarakan ide yang merupakan bentuk kreativitas sebagai upaya memahami materi. Selain itu, pengajaran yang membosankan dan pemanfaatan fasilitas yang kurang optimal di sekolah seperti penggunaan alat-alat percobaan yang dibatasi.

Hal inilah yang menjadi
penghambat


kreativitas peserta didik. Fakta ini menyebabkan peserta didik beranggapan bahwa pelajaran fisika adalah pelajaran yang sulit dan sangat membosankan. Hal ini dapat dilihat dari nilai fisika semester 1 kelas X MIA yang ditunjukkan pada tabel 1.

Tabel 1. Nilai Rata-Rata Ulangan Akhir Fisika Semester 1 Tahun Pelajaran

\begin{tabular}{cccc}
\multicolumn{4}{c}{ 2017/2018 } \\
\hline No. & Kelas & $\begin{array}{c}\text { Nilai rata- } \\
\text { rata }\end{array}$ & KKM \\
\hline 1 & X MIA 1 & 37,16 & 76 \\
2 & X MIA 2 & 38,24 & 76 \\
3 & X MIA 3 & 39,94 & 76 \\
4 & X MIA 4 & 37,00 & 76 \\
5 & X MIA 5 & 35,72 & 76 \\
6 & X MIA 6 & 37,85 & 76 \\
7 & X MIA 7 & 35,83 & 76 \\
\hline
\end{tabular}

Melihat hal-hal tersebut, maka guru dituntut untuk dapat memilih dan menerapkan model pembelajaran yang sesuai berdasarkan kondisi peserta didik dengan tujuan supaya peserta didik berperan aktif dalam pembelajaran, sehingga mata pelajaran fisika tidak terkesan sulit dan membosankan serta kegiatan belajar mengajar akan lebih bermakna. Jadi, dari permasalahan di atas peneliti tertarik untuk melakukan penelitian terhadap pengaruh model pembelajaran kooperatif tipe Numbered Heads Together (NHT) berbantuan LKPD terhadap kemampuan berpikir kreatif fisika peserta didik di SMAN 3 Mataram. Dalam pembelajaran kooperatif, proses pembelajaran tidak harus belajar dari guru kepada peserta didik, peserta didik dapat saling membelajarkan sesama peserta didik lainnya. Menurut Prasetyo dalam Hikmawati (2013) Pembelajaran kooperatif adalah suatu teknik pembelajaran atau suatu filsafat pengajaran yang dapat membangkitkan semangat untuk bekerjasama guna memaksimalkan pengetahuan mereka (peserta didik) masing-masing atau pengetahuan teman-temannya dalam satu kelompok kecil secara kolaboratif yang anggotanya terdiri dari 4-6 orang dengan struktur kelompok yang bersifat heterogen.

Dalam pembelajaran kooperatif, guru lebih berperan sebagai fasilitator yang berfungsi sebagai jembatan penghubung ke arah pemahaman yang lebih tinggi. Guru tidak hanya memberikan pengetahuan kepada peserta didik, tetapi juga harus membangun pengetahuan dalam pikirannya. Peserta didik mempunyai kesempatan untuk mendapatkan pengalaman langsung dalam menerapkan ide-ide mereka. Dalam menerapkan ide-ide tersebut, guru dapat memilih salah satu model atau jenis pembelajaran kooperatif yang mengharuskan peserta didik menyampaikan pendapat atau ide-idenya, salah satunya adalah model pembelajaran kooperatif tipe Numbered Heads Together (NHT).

NHT merupakan salah satu pembelajaran yang berorientasi pada siswa, yakni dengan melakukan pembelajaran secara berkelompok dan berpusat pada siswa, dimana lebih menekankan pada struktur khusus yang dirancang untuk mempengaruhi pola interaksi siswa (Rahmawati, et al, 2014). Pembelajaran kooperatif tipe NHT dapat melatih peserta didik dalam mengembangkan kemampuan berpikir yang ada dalam peserta didik dan memberikan tanggung jawab pada masingmasing individu dalam pelaksanaan kegiatan pembelajaran. Ada 4 fase pembelajaran NHT yaitu penomoran, mengajukan pertanyaan, berpikir bersama, dan menjawab (Siregar, et al, 2013). Pembelajaran tipe NHT lebih bermakna dengan bantuan media atau alat bantu pembelajaran seperti penggunaan LKPD. LKPD merupakan bahan ajar yang dikembangkan oleh guru sebagai fasilitator dalam pembelajaran, berisi tugas yang harus dikerjakan oleh peserta didik sebagai bentuk latihan yang bertujuan agar dapat memahami dan mengerti tentang 
materi yang diajarkan (Arief, 2015). Penggunaan LKPD dalam kegiatan pembelajaran dapat mendorong peserta didik untuk mengolah bahan yang dipelajari, baik secara individu maupun bersama dengan temannya dalam bentuk diskusi kelompok. LKPD juga dapat memberikan kesempatan penuh kepada peserta didik untuk mengungkapkan kemampuannya dalam keterampilan pengembangan proses berpikir melalui mencari, menebak bahkan menalar. Dengan pengembangan proses berpikir tersebut, maka dapat mengaktifkan peserta didik dalam proses pembelajaran.

Kemampuan berpikir yang dimaksud adalah kemampuan berpikir kreatif. Kemampuan berpikir kreatif adalah hasil interaksi antara individu dan lingkungannya. Seseorang mempengaruhi dan dipengaruhi oleh lingkungan di mana ia berada, dengan demikian baik perubahan di dalam individu maupun di dalam lingkungan dapat menunjang atau menghambat kemampuan berpikir kreatif. Gunawan et al., (2017) mengungkapkan bahwa berpikir kreatif diperoleh dari kebiasaan yang dapat diperoleh peserta didik dengan menemukan dan menggunakan ide-ide baru yang tidak biasa namun masih rasional dalam mengikuti pembelajaran. Menurut Ekasari, et al (2016) berpikir kreatif atau kreativitas merupakan kemampuan seseorang untuk menghasilkan suatu produk yang baru ataupun kombinasi dari hal-hal yang sudah ada sebelumnya, yang berguna, serta dapat dimengerti. Anwar dalam Yusro (2015) menyatakan bahwa berfikir kreatif adalah cara baru dalam melihat dan mengerjakan sesuatu yang memuat 4 aspek antara lain, fluency (kelancaran), flexybility (keluwesan), originality (keaslian), dan elaboration (keterincian).

\section{METODE PENELITIAN}

Jenis penelitian yang digunakan adalah penelitian kuasi eksperimen karena ditandai dengan adanya perlakuan yang dirancang dan diberikan secara sengaja untuk mengubah kondisi. Pada penelitian ini ada dua variabel yang menjadi fokus penelitian yaitu variabel bebas berupa model pembelajaran kooperatif tipe NHT dan variabel terikat adalah kemampuan berpikir kreatif. Desain penelitian yang digunakan adalah untreated control group design with pretest and posttest.

Adapun Teknik pengambilan sampel dilakukan dengan teknik purposive sampling, yakni teknik di mana peneliti mempunyai pertimbangan-pertimbangan khusus berkenaan dengan sampel yang diambil. Sampel yang dipergunakan dalam penelitian ini yaitu peserta didik kelas XI MIA 3 sebagai kelas eksperimen yang berjumlah 38 orang dan XI MIA 4 sebagai kelas kontrol yang berjumlah 37 orang. Pertimbangan peneliti mengambil sampel tersebut karena pada kedua sampel ini mempunyai latar belakang pengetahuan yang setara, sampel yang dipilih adalah individu atau personal yang mudah didekati atau ditemui oleh peneliti.

Instrumen yang digunakan untuk mengukur kreativitas ada dua jenis yaitu TKV (Tes Kreativitas Verbal) sebanyak 7 soal uraian dan TKF (Tes Kreativitas Figural) sebanyak 3 soal uraian. Indikator yang digunakan dalam tes kreativitas ini adalah (a) Kelancaran (fluency) Keluwesan (flexibility) (c) Keaslian (originality) (d) Terperinci (elaboration).

Sebelum instrumen TKV dan TKF digunakan, instrumen di uji validitas butir soal menggunakan persamaan korelasi product moment. Analisis data yang digunakan dalam penelitian ini adalah uji homogenitas menggunakan uji-F, pada taraf signifikan $5 \%$ jika $F_{\text {hitung }} \leq \mathrm{F}_{\text {tabel, }}$, data homogen dan jika $F_{\text {hitung }}>F_{\text {tabel }}$, data tidak homogen, uji normalitas menggunakan persamaan Chi-kuadrat, $\chi_{\text {hitung }}{ }^{2}<\chi_{\text {tabel }}{ }^{2}$ data 
terdistribusi normal dan $\chi_{\text {hitung }}{ }^{2}>\chi_{\text {tabel }}{ }^{2}$ data terdistribusi tidak normal dengan taraf signifikansi $5 \%$ dan derajat kebebasan, $\mathrm{dk}=\mathrm{k}-1$, dimana $\mathrm{k}$ menyatakan jumlah kelas interval. Untuk mengetahui peningkatan nilai sebelum dan sesudah perlakuan digunakan uji-t Polled Varian.

\section{HASIL DAN PEMBAHASAN}

Hasil penelitian berupa deskripsi hasil tes awal dan tes akhir dengan menggunakan uji normalitas, uji homogenitas dan uji hipotesis.

Penelitian ini bertujuan untuk mengetahui pengaruh model pembelajaran kooperatif tipe NHT berbantuan LKPD terhadap kemampuan berpikir kreatif fisika peserta didik di SMAN 3 Mataram. Kemampuan berpikir kreatif yang dimaksud adalah kemampuan peserta didik untuk menghasilkan suatu produk yang baru ataupun kombinasi dari hal-hal yang sudah ada sebelumnya, yang berguna serta dapat dimengerti. Tes kemampuan berpikir kreatif diberikan sebelum dan sesudah perlakuan melalui tes awal dan tes akhir. Sebelum instrumen tes awal diberikan pada kelas eksperimen dan kontrol, peneliti terlebih dahulu melakukan validasi empiris dengan uji coba instrumen di kelas XII IPA 4 yang telah mempelajari materi elastisitas dan hukum Hooke.

Analisis data yang dilakukan berdasarkan tes awal dan tes akhir, menunjukkan bahwa terdapat peningkatan kemampuan berpikir kreatif pada kedua kelas. Nilai tes awal peserta didik pada kedua kelas sama-sama rendah, hal ini disebabkan karena peserta didik belum menerima pembelajaran tentang materi elastisitas dan hokum Hooke. Selanjutnya setelah diberikan perlakuan nilai yang diperoleh kedua kelas mengalami peningkatan, namun terdapat perbedaan antara kemampuan berpikir kreatif peserta didik yang proses pembelajarannya menggunakan model pembelajaran kooperatif tipe NHT berbantuan LKPD dengan proses pembelajarannya menggunakan pengajaran langsung. Hasil tes awal dan tes akhir kedua kelas dapat dilihat pada tabel 2 berikut.

Tabel 2. Nilai Rata-rata Kedua Kelas

\begin{tabular}{lcc}
\hline \multicolumn{1}{c}{ Kelas } & Kemampuan & Rata-rata \\
\hline Eksperimen & Awal & 34,49 \\
\multirow{3}{*}{ Kontrol } & Akhir & 53,75 \\
& Awal & 34,29 \\
& Akhir & 52,21 \\
\hline
\end{tabular}

Data pada tabel 2 diperlihatkan bahwa nilai rata-rata tes awal kelas eksperimen lebih besar yaitu 34,49, sedangkan nilai rata-rata kelas kontrol sebesar 34,29. Setelah kedua kelas diberi perlakuan, kemampuan berpikir kreatif fisika peserta didik pada tes akhir untuk kelas eksperimen meningkat menjadi 53,75 lebih tinggi daripada kelas kontrol dengan nilai rata-rata 52,21. Nilai rata-rata tes akhir menunjukkan bahwa kemampuan berpikir kreatif fisika kelas eksperimen dan kelas kontrol sama-sama mengalami peningkatan. Kelas eksperimen mengalami peningkatan nilai rata-rata sebesar 19,26, sedangkan kelas kontrol mengalami peningkatan sebesar 17,92. Hasil tersebut menunjukkan bahwa peningkatan nilai rata-rata kelas eksperimen lebih baik dari kelas kontrol seperti yang diperlihatkan pada Gambar 1 . Artinya, terdapat pengaruh positif dari model pembelajaran kooperatif tipe NHT berbantuan LKPD pada kelas eksperimen.

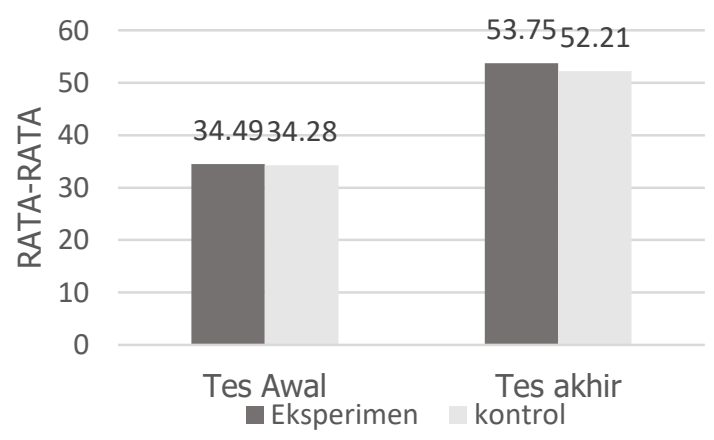

Gambar 1. Kemampuan Berpikir Kreatif Fisika Peserta Didik 
Berdasarkan hasil perhitungan tes awal dan tes akhir kemampuan berpikir kreatif fisika peserta didik pada tiap-tiap indikator, didapatkan persentase seperti ditunjukkan pada tabel 3 berikut.

Tabel 3. Nilai Rata-rata Kemampuan Berpikir Kreatif Fisika Peserta Didik (\%)

\begin{tabular}{ccccc}
\hline Indikator & \multicolumn{2}{c}{ Kelas } & \multicolumn{2}{c}{ Kelas Kontrol } \\
& Eksperimen & & \\
\cline { 2 - 5 } & Tes & Tes & Tes & Tes \\
& Awal & Akhir & Awal & Akhir \\
& $\%$ & $\%$ & $\%$ & $\%$ \\
Kelancaran & 45 & 78 & 38 & 66 \\
Flexibilitas & 33 & 55 & 39 & 56 \\
Originalitas & 27 & 58 & 26 & 42 \\
Perincian & 31 & 57 & 38 & 49 \\
\hline
\end{tabular}

Data pada Tabel 3 menunjukkan hasil persentase nilai rata-rata kemampuan berpikir kreatif fisika peserta didik pada tes awal dan tes akhir. Persentase nilai rata-rata tes awal yang diperoleh sampel kelas eksperimen pada indikator kelancaran sebesar $45 \%$, flexibilitas $33 \%$, originalitas $27 \%$ dan perincian $31 \%$. Sedangkan persentase nilai rata-rata tes awal yang diperoleh sampel kelas kontrol pada indikator kelancaran sebesar 38\%, flexibilitas $39 \%$, originalitas $26 \%$ dan perincian $38 \%$.

Selanjutnya, persentase nilai ratarata tes akhir kemampuan berpikir kreatif fisika peserta didik pada tes yang diperoleh sampel kelas eksperimen pada indikator kelancaran sebesar $78 \%$, flexibilitas $55 \%$, originalitas $58 \%$ dan perincian $57 \%$. Dan persentase nilai rata-rata tes akhir kemampuan berpikir kreatif fisika peserta didik pada kelas kontrol untuk indikator kelancaran sebesar $66 \%$, flexibilitas $56 \%$, originalitas $42 \%$ dan perincian $49 \%$.

Pengujian data diawali dengan pengujian homogenitas data dan normalitas data tes awal dan tes akhir. Tujuannya adalah untuk menentukan jenis uji hipotesis yang akan digunakan. Uji homogenitas sebaran data menggunakan uji-F sedangkan untuk uji normalitas digunakan persamaan Chi-Kuadrat. Berdasarkan data tes awal yang diperoleh pada kelas eksperimen dan kelas kontrol, didapatkan bahwa $F_{\text {hitung }}<$ $\mathrm{F}_{\text {tabel, }}$ maka kedua sampel dikatakan homogen. Pada tes akhir juga terlihat bahwa $F_{\text {hitung }}<F_{\text {tabel}}$, sehingga kedua sampel dikatakan homogen. Selanjutnya dilakukan uji normalitas data tes awal dan tes akhir pada masing-masing kelas. Berdasarkan perhitungan yang telah dilakukan diperoleh hasil bahwa $\chi_{\text {hitung }}{ }^{2}<$ $\chi_{\text {tabel }^{2}}{ }^{2}$ artinya bahwa sebaran data terdistribusi normal pada tes awal dan tes akhir baik kelas eksperimen maupun kelas kontrol. Hasil ini menunjukkan bahwa uji hipotesis yang digunakan adalah uji-t.

Selanjutnya digunakan uji-t polled varians karena sampel pada penelitian ini berbeda $\left(\mathrm{n}_{1} \neq \mathrm{n}_{2}\right)$. Berdasarkan uji statistik yang dilakukan didapatkan nilai $t_{\text {tabel }}$ pada taraf signifikan 5\%. Berdasarkan kriteria bahwa jika $t_{\text {hitung }}>t_{\text {tabel }}$ maka Ha ditolak dan Ho diterima, sehingga hasil uji tersebut menunjukkan adanya pengaruh model pembelajaran kooperatif tipe NHT berbantuan LKPD terhadap kemampuan berpikir kreatif fisika peserta didik.

Berdasarkan hasil uji $\mathrm{N}$-gain antara kelas eksperimen dan kelas kontrol yang dianalisis pada setiap indikatornya, menunjukkan terjadi peningkatan yang baik pada kelas eksperimen. Perolehan hasil uji $\mathrm{N}$-gain kelas eksperimen pada indikator kelancaran, flexibilitas, originalitas, dan perincian secara berturut-turut sebesar 60, $32 \%$; 33,25\%; 41,87\%; dan 37,78\% dengan nilai rata-rata $\mathrm{N}$-gain sebesar $41 \%$ dan termasuk dalam kategori sedang. Sementara itu kelas kontrol memperoleh kategori rendah dengan persentase secara berturutturut pada empat indikator yaitu sebesar $45,26 \%$; $28,31 \%$; $21,51 \%$; dan $17,34 \%$ dengan nilai rata-rata $\mathrm{N}$-gain sebesar $27 \%$. Untuk lebih jelasnya, perolehan persentase nilai rata-rata $\mathrm{N}$-gain kelas eksperimen dan 
kelas kontrol ditunjukkan pada gambar berikut.

Hasil penelitian menggambarkan bahwa kemampuan berpikir kreatif fisika peserta didik mengalami peningkatan pada kedua kelas, namun peningkatan pada kelas eksperimen lebih baik daripada kelas kontrol. Hal tersebut terjadi karena pembelajaran menggunakan model pembelajaran kooperatif tipe NHT memudahkan peserta didik dalam menyelesaikan dan mendiskusikan suatu permasalahan melalui empat langkah pembelajaran NHT yang di susun secara sistematis dengan berbantuan LKPD.

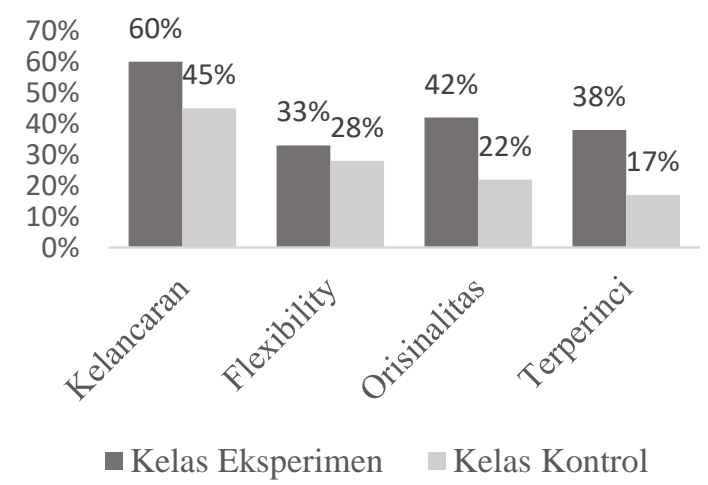

Gambar 2. Rata-rata N-gain Kemampuan Berpikir Kreatif Fisika Peserta Didik

Pembelajaran di dalam kelas tidak cukup hanya dengan menerapkan model karena suatu model pembelajaran perlu dilengkapi dengan media atau perangkat pembelajaran untuk membantu peserta didik lebih memahami apa yang dipelajari pada proses pembelajaran.

Pada saat pembelajaran, peserta didik kelas eksperimen lebih aktif bertanya ataupun berdiskusi dibandingkan dengan kelas kontrol. Peserta didik pada kelas eksperimen cukup antusias dengan adanya LKPD yang diberikan. Sedangkan pada kelas kontrol tidak menunjukkan hal demikian karena saat pembelajaran berlangsung hanya diberikan lembar kerja yang berisi soal-soal tanpa ringkasan materi, dan contoh soal serta penyelesaiannya. Akibatnya, nilai rata-rata kemampuan berpikir kreatif pada kelas eksperimen dengan model pembelajaran kooperatif tipe NHT berbantuan LKPD lebih tinggi daripada kelas kontrol dengan pengajaran langsung. Hal ini menunjukkan bahwa kelas eksperimen lebih baik dibandingkan kelas kontrol. Menurut Aji \& Widodo (dalam Nur, 2017), lembar kerja peserta didik (LKPD) berfungsi sebagai penuntun peserta didik untuk menyelesaikan suatu masalah dalam pembelajaran.

Hasil penelitian yang sudah dilakukan menggambarkan bahwa kemampuan berpikir kreatif fisika yang dimiliki peserta didik berbeda dengan kemampuan awalnya. Kelas eksperimen maupun kelas kontrol mengalami peningkatan, namun peningkatan kelas eksperimen lebih baik daripada kelas kontrol. Hal ini disebabkan oleh penggunaan model pembelajaran kooperatif tipe NHT berbantuan LKPD pada kelas eksperimen. Berdasarkan analisis data hasil penelitian bahwa model pembelajaran kooperatif tipe NHT berbantuan LKPD pada pembelajaran elastisitas dan hukum Hooke dapat meningkatkan kemampuan berpikir kreatif fisika peserta didik.

Temuan dalam penelitian ini memperkuat beberapa penelitian sebelumnya salah satu diantaranya adalah penelitian yang dilakukan oleh Susanti, et al (2016), Model pembelajaran kooperatif tipe NHT berbantuan kartu soal dapat dijadikan sebagai alternatif model pembelajaran yang dapat diterapkan untuk mengaktifkan peserta didik, sehingga hasil belajar kognitif peserta didik meningkat. Selain itu Nisrina et al. (2016) juga mengungkapkan bahwa Penerapan model pembelajaran kooperatif dengan media virtual berpengaruh terhadap penguasaan 
konsep fisika siswa pada materi fluida statis secara signifikan.

\section{PENUTUP}

Berdasarkan hasil penelitian yang telah dilaksanakan dapat disimpulkan bahwa terdapat pengaruh model pembelajaran kooperaif tipe Numbered Heads Together (NHT) berbantuan LKPD terhadap kemampuan berpikir kreatif fisika peserta didik di SMAN 3 Mataram. Adapun saran yang dapat diberikan (1) Penggunaan model pembelajaran kooperatif tipe NHT diharapkan dapat meningkatkan kreativitas dan peserta didik lebih aktif selama kegiatan pembelajaran. (2) Bagi guru, pembelajaran fisika dengan model pembelajaran kooperatif tipe NHT dapat dijadikan sebagai salah satu alternatif yang dapat diterapkan untuk meningkatkan kreativitas peserta didik. (3) Bagi peneliti lain yang ingin meneliti pengaruh model pembelajaran kooperatif tipe NHT untuk memperhatikan materi dan instrumen tes yang digunakan, terutama untuk instrumen tes kreativitas verbal dan figural.

\section{REFERENSI}

Arief, M. F. M. 2015. Pengembangan Lembar Kerja Siswa (LKS) pada Pembelajaran Mekanika Teknik dengan Pendekatan Kontekstual untuk Siswa Kelas X TGB SMK Negeri 2 Surabaya. Jurnal Pendidikan Teknik Bangunan. 1(1): 148-152.

Ekasari, R.R., Gunawan, dan Sahidu, H. 2016. Pengaruh Model Pembelajaran Langsung Berbantuan Media Laboratorium Terhadap Kreatifitas Fisika Siswa SMA. Jurnal Pendidikan Fisika dan Teknologi. 2(3): 107.

Gunawan, G., Sahidu, H., Harjono, A., \& Suranti, N. M. Y. The Effect of Project Based Learning with Virtual Media Assistance on Student's
Creativity in Physics. Cakrawala Pendidikan, (2), 167-179.

Hikmawati. 2013. Strategi Pembelajaran Fisika. Mataram: FKIP Press.

Nur, M., Sahidu, H., dan Kosim. 2017. Pengaruh Model Pemecahan Masalah Polya Berbantuan LKPD Terhadap Kemampuan Menganalisis Materi Fisika Peserta Didik SMAN 1 Selong Tahun Pelajaran 2016/2017. Jurnal Pendidikan Fisika dan Teknologi. 3(2): 161.

Rahmawati, D., Nugroho, S. E., dan Putra, N. M. D. 2014. Penerapan Model Pembelajaran Kooperatif Tipe Numbered Heads Together Berbasis Eksperimen untuk Meningkatkan Keterampilan Proses Sains Siswa SMP. Unnes Physics Education Journal. 3(1): 40-45

Siregar, R. W., Djamas, D., dan Nurhayati. 2013. Pengaruh Model Pembelajaran Kooperatif Tipe Numbered Heads Together Berbantuan Handout Terhadap Hasil Belajar Fisika Siswa Kelas XI IPA SMAN 7 Padang. Pillar of Physics Education. 1(1): 7176.

Susanti, F., Ayub, S., dan Taufik, M. 2016. Perbedaan Hasil Belajar Fisika Melalui Model Pembelajaran Kooperatif Tipe Numbered Heads Together (NHT) Berbantuan Kartu Soal dengan Model Pembelajaran Direct Instruction di SMAN 7 Mataram Tahun Ajaran 2016/2017. Jurnal Pendidikan Fisika dan Teknologi. 2(4): 147-152.

Yusro, A. C. 2015. Pengembangan Perangkat Pembelajaran Fsika Berbasis Sets Untuk Meningkatkan Kemampuan Berpikir Kreatif Siswa. Jurnal Penelitian Fisika Kependidikan (JPFK). 1(2): 6166. 